\title{
Soft sediment deformation structures in Silurian turbidites from North Greenland
}

\author{
POULHENRIK LARSEN
}

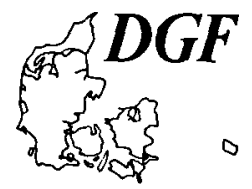

Larsen, P.-H.: Soft sediment deformation structures in Silurian turbidites from North Greenland. Bull. geol. Soc. Denmark, vol. 35, pp. 19-23, Copenhagen, October, 29th, 1986. https://doi.org/10.37570/bgsd-1986-35-03

\begin{abstract}
Turbidite beds in the Silurian turbidite sequence, North Greenland, show soft sediment deformation struc-tures suggesting that the structureless (in respect of traction structures) sandstones divisions of the turbidi-tes were deposited by direct suspension sedimentation from high-density flows. The deposits may have re-sulted from multiple successive depositional events within the same turbidity flow. Reworking and shear- ing of the newly formed loosely packed high-density suspension deposits caused by the still moving flow above create secondary soft sediment deformation structures which may be used as current indicators if other structures are absent (e.g. flute casts).
\end{abstract}

P.-H. Larsen, Grønlands Geologiske Undersøgelser, Øster Voldgade 10, DK-1350 Copenhagen K, Denmark. May 6th, 1985.

\section{General aspects of turbidite} sedimentation

The organisation of deposits from low-density turbidity currents, the classical Bouma model, has been extensively discussed and reviewed by Bouma (1962), Walker (1965), Sanders (1965), Middleton (1967, 1969, 1970), Walton (1967), Allen (1970) and Middleton \& Hampton (1973, 1976) among others.

Lowe (1982) pointed out that there is no experimental or theoretical evidence indicating that the Ta-division of Bouma's (1962) model forms by high-velocity traction sedimentation. Experimental results seem to suggest that it is deposited by direct suspension sedimentation from highdensity flows (Middleton 1967). The deposition of a dense cohesionless suspension can be described in terms of a liquified bed (Wallis 1969) lacking traction structures. The bed can be massive or show penecontemporaneous water-escape structures developed during mass settling. The stage of suspension sedimentation probably accounts for the bulk of the high-density suspended load and can form almost instantaneously (Lowe 1982).

Deposition of the high-density suspended sediment load leaves a residual current containing fine sand, silt and clay in a turbulent suspension. These residual currents may complete bypass areas of high-density turbidity current deposition, but may have significant local effects. They may shear, liquify and homogenise the loosely packed high-density suspension deposits (Middleton 1967; Lowe 1982). Unsteady, residual low density currents can deposit sediment above that laid down during the high-density depositional stages. Such deposits often include climbing ripple cross-lamination (Lowe 1982) (fig. 1). Fluctuations in the rate of suspended load fall-out may result in traction sedimentation, traction carpet sedimentation or suspension sedimentation at almost any stage until the high-density turbidity current has declined to a low-density flow (Lowe 1982).

The purpose of this paper is to show from soft sediment deformation features of certain turbidite beds in the Silurian turbidite sequence, North Greenland (Hurst \& Surlyk 1982; Surlyk \& Hurst 1984; Larsen \& Escher 1985, in prep) that deposition from sandy high-density turbidity currents may take place in not only one but multiple successive events and that the still moving turbidity flow above may rework the newly formed loosely packed deposits. 


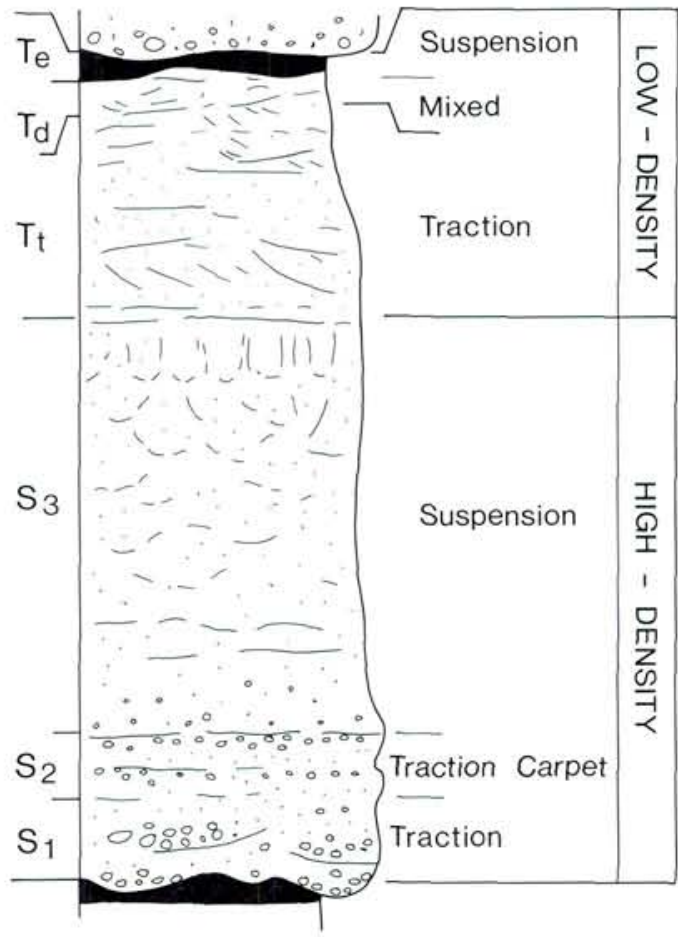

Fig. 1. Ideal deposit of a sandy high-density turbidity current showing both high-density (S1-3) and late-stage low-density (Tt, Td-e) divisions. The Tt-division comonly includes a Tc-division at the top, lower layers of flat-lamination (Tb-division). and large-scale cross-stratification that is not part of the normal Bouma sequence (modified from Lowe, 1982).

\section{Sedimentary structures}

\section{Flame structures}

Three successive levels of flame structures occurring in a single turbidite bed have been observed at one locality (fig. 2). The two lower levels are characterised by dark coloured argillaceous finegrained sand injected upwards into light coloured fine-grained sand giving rise to the 'flames'. The 'flames' are evenly spaced approximately $2 \mathrm{~cm}$ apart at both levels. The third level shows oblique 'flames', probably generated in the same way as the two lower levels but disturbed by later soft sediment deformation (fig. 2). Above this level the turbidite bed is virtually structureless and massive.

Flame structures occur in another turbidite bed (fig. 3) approximately $5 \mathrm{~cm}$ above the base of the bed in a $2-3 \mathrm{~cm}$ thick horizon. The 'flames' are evenly spaced c. $2 \mathrm{~cm}$ apart and occur as dark col- oured argillaceous fine-grained sand injected upwards into light coloured fine-grained sand. The upper part of the 'flames' is disturbed by later soft sediment deformation giving rise to a horizon of oblique 'flames' (fig. 3). Above the oblique 'flames' the turbidite is structureless and massive until $19 \mathrm{~cm}$ above the base where $15 \mathrm{~cm}$ of cross-laminated very fine-grained sand tops the bed.

The observed turbidite (fig. 3) cannot be described in terms of the classical Bouma model as it has a basal 1-2 $\mathrm{cm}$ thick cross-laminated zone succeeded by a $2-3 \mathrm{~cm}$ thick structureless zone
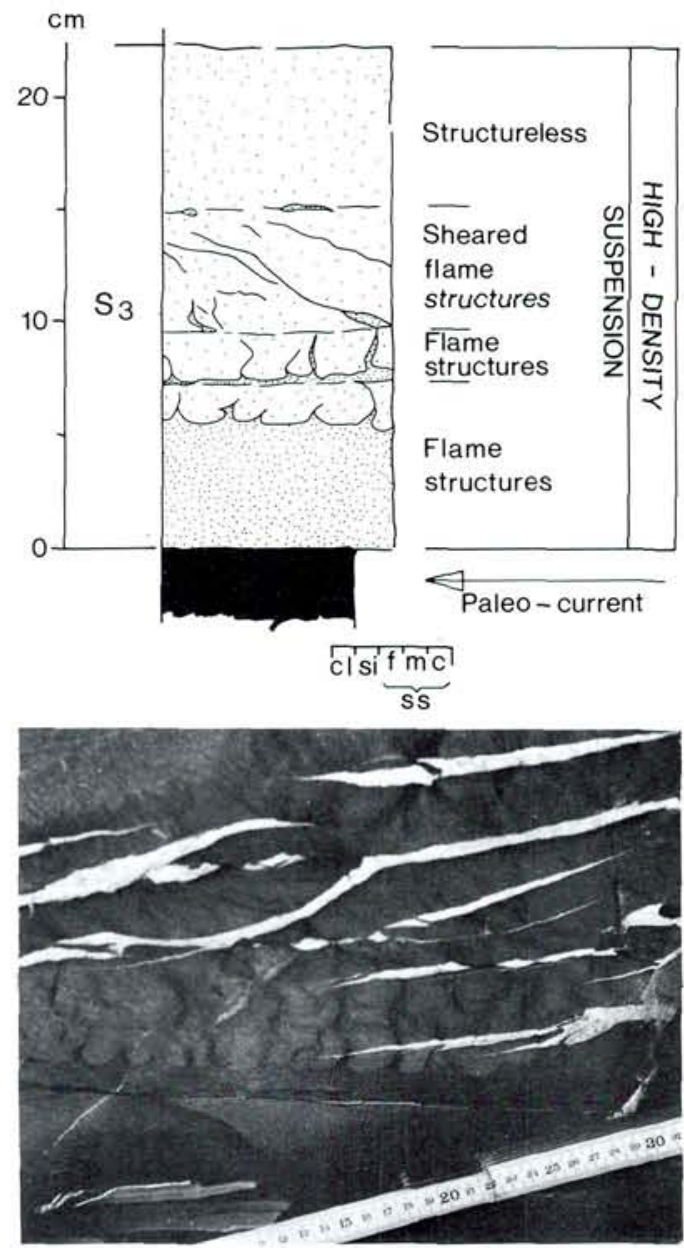

Fig. 2. Flame structures in three different successive levels in a fine-grained sandstone turbidite bed without traction structures occurring $585 \mathrm{~m}$ above the base of the Lauge Koch Land Formation. Hand Bugt, northern Nyeboe Land (Larsen \& Escher in prep., section 14b). The 'flames' have been sheared in the upper level. White calcite veins are due to post-depositional regional deformation. 

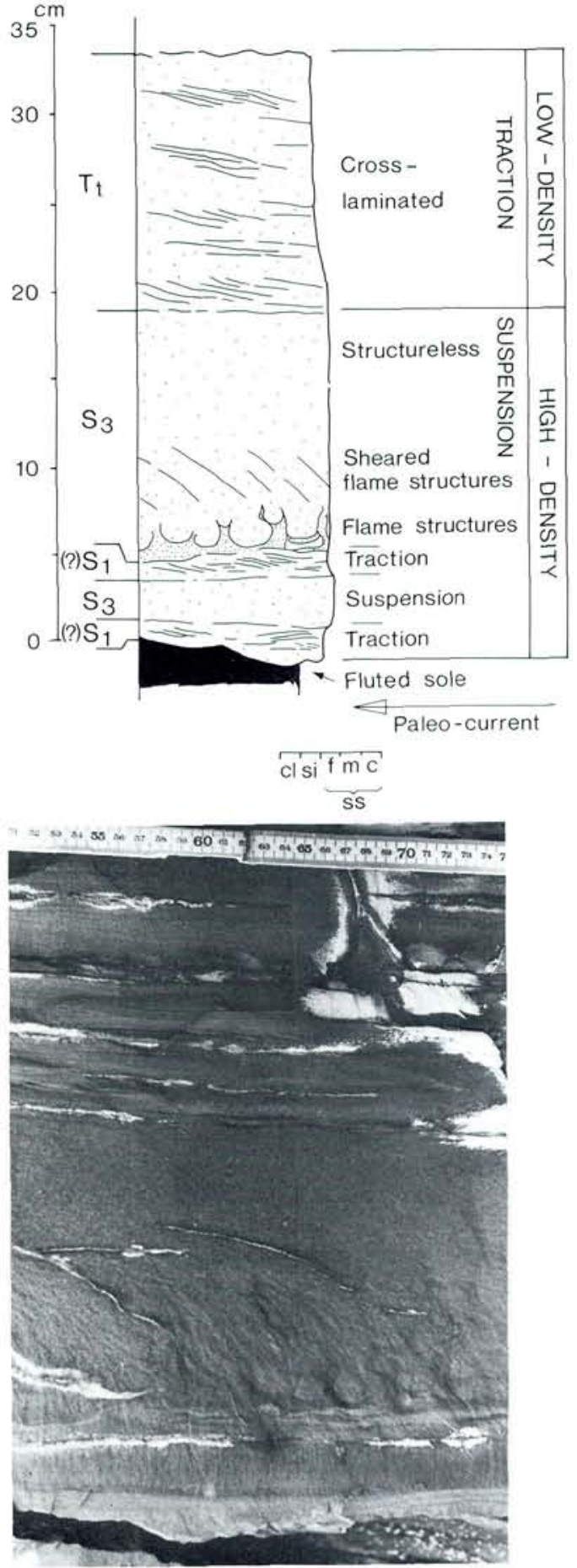

Fig. 3. Flame structures in a fine-grained sandstone turbidite bed occurring $290 \mathrm{~m}$ above the base of the Lauge Koch Land Formation. Hand Bugt, northern Nyeboe Land (Larsen \& Escher in prep., section 14b). The 'flames' have been sheared in their upper parts. The paleo-current direction is from right to left, and the sheared 'flames' are thus upstream inclined.
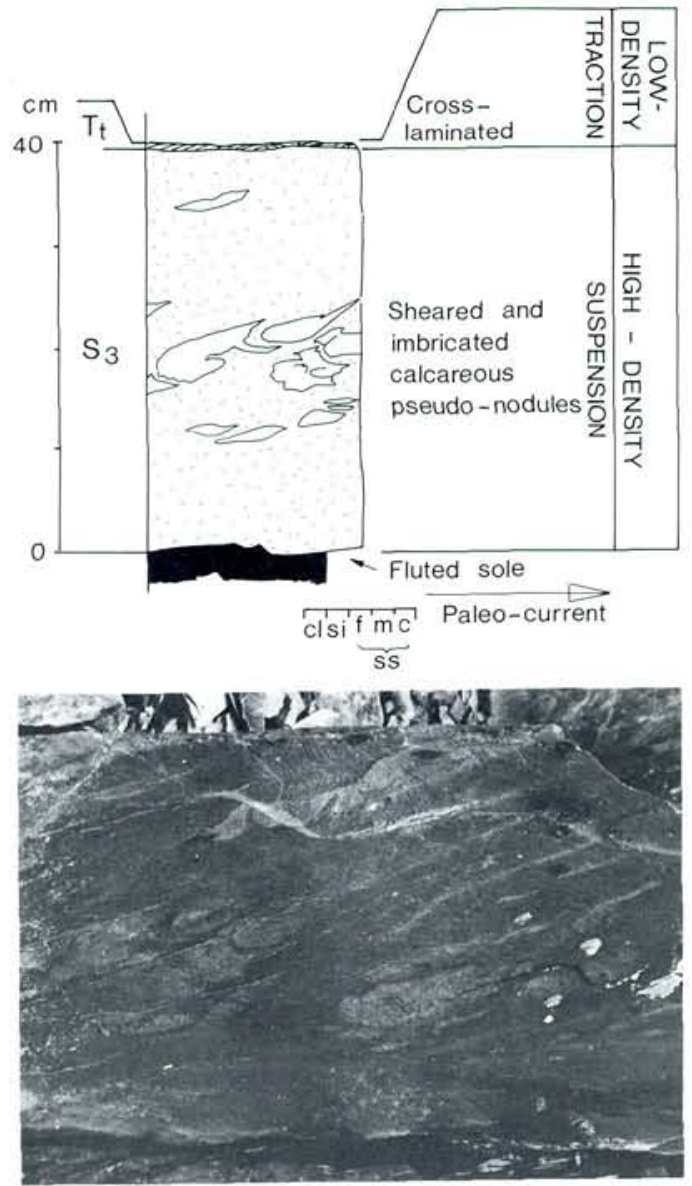

Fig. 4. Calcareous pseudo-nodules in a fine-grained sandstone turbidite bed occurring $22 \mathrm{~m}$ above the base of the Merqujoq Formation. Hand Bugt, northern Nyeboe Land (Larsen \& Escher in prep., section 14a). The paleo-current direction is from left to right and the pseudo-nodules are thus upstream inclined.

which again is succeeded by a cross-laminated zone before the 'structureless' bed containing the flame structures. The turbidite has a fluted sole indicating the paleo-current, which shows that the disturbed oblique, 'flame' structures are upstream inclined (fig. 3).

Pseudo-nodules

Grey weathering spots or pseudo-nodules high in carbonate content give some calcareous turbidites a mottled appearance (fig. 4). This bed is $40 \mathrm{~cm}$ thick and devoid of primary current produced sedimentary structures except for a $1 \mathrm{~cm}$ thick cross-laminated horizon at the top. The pseudo-nodules are characteristically formed as 
upstream imbricated or inclined ellipsoids, which is shown by the fluted sole of the turbidite bed (fig. 4).

\section{Discussion}

The fine-grained sand divisions of the described beds are interpreted as deposited by rapid direct suspension sedimentation from high-density turbidite flows following the concepts of Lowe (1982). The generation of the observed flame structures is penecontemporaneous in respect of the deposition, and may be a combination of slight reverse density gradients and liquifaction of the lower layer resulting in loading and expulsion of excess pore water. Skipper \& Middleton (1975) have described generation of calcareous speudo-nodules in turbidites resulting from loading of a denser calcareous bed into a liquified lower bed. This may also be the primary origin of the disturbed pseudo-nodules (fig. 4).

The occurrence of three successive levels of flame structures in the turbidite bed (fig. 2) suggests that rapid direct suspension sedimentation from a high-density turbidite flow is not necessarily limited to one event but may take place several times from the same turbidite flow.

The upper parts of the flame structures (fig. 2 and 3) as well as the calcareous pseudo-nodules (fig. 4) have been disturbed by secondary soft sediment deformation, probably caused by shear stresses exerted on recently deposited and still unconsolidated sediment by the flow still moving above. This flow may be interpreted as a late stage residual current or low-density turbidity flow (Lowe 1982) causing the reworking of the high-density turbidity current deposits below and the deposition of cross-laminated sand (Tc-division) on the top (figs. 3,4 ).

When flute-casts are observed at the sole of the turbidites, the sheared and deformed flame structures and pseudo-nodules can be seen to be inclined or imbricated upstream. This is the case where both kind of structures have been observed in the same turbidite bed in the field, and it is therefore suggested that secondary sheared soft-sediment deformation structures may serve as a paleo-current indicator if other traction structures or sole marks are absent.

\section{Conclusions}

1. Following the concepts of Lowe (1982) soft sediment deformation structures within the structureless (in respect of traction structures) sandstone divisions of certain turbidites from North Greenland suggest that these were deposited from high-density flows, and that the deposits may be a result of multiple successive depositional events within the same high-density turbidity flow.

2. After deposition of the structureless sand divisions the high-density flows turn into low-density flows or late stage residual currents, which may exerte shear stresses upon the recently deposited and still unconsolidated sediments. The shearing can deform the newly formed soft sediment deformation structures. Oblique 'flames' and pseudo-nodules are created which both are inclined upstream and thus may be proposed as paleo-current indicators if other structures are absent.

3. Penecontemporaneously to the reworking or shearing of the newly formed high-density turbidity current deposits, the late stage residual current or low-density flow forms a sandstone division on the top containing traction structures, which in the discussed examples all are crosslaminations (Tc-division) and can be designated to the classical Bouma model.

Acknowledgements. The author is indebted to F. Surlyk for critically reviewing the manuscript and to B. Thomas, V. Hermansen and $\mathrm{E}$. Glendal for technical assistance. This paper is published with the permission of the Director of the Geological Survey of Greenland.

\section{Dansk sammendrag}

I turbiditer fra den silure turbiditsekvens i Nordgrønland forekommer soft-sediment strukturer som indicerer, at den strukturløse (med hensyn til traction strukturer) sandstensdivision $\mathrm{i}$ turbiditerne blev aflejret ved hurtig, direkte suspensions-sedimentation fra high-density flows. Disse aflejringer er $\mathrm{i}$ visse tilfælde et resultat af multible hændelser inden for samme turbidit flow. Efterfølgende residualstrømme eller low-density flows har genoparbejdet og sheared de løst pakkede high-density suspensionsaflejringer, hvilket har resulteret $i$ sekundære softsediment strukturer, der tilsyneladende kan anvendes som strømindikatorer, hvis andre strukturer, så som flute casts, ikke findes. 


\section{References}

Allen, J. R. L. 1970: The sequence of sedimentary structures in turbidites, with special reference to dunes. Scott, J. Geol. $6,146-161$.

Bouma, A. H. 1962: Sedimentology of some flysch deposits. Amsterdam: Elsevier, $168 \mathrm{pp}$.

Hurst, J. M. \& Surlyk, F. 1982: Stratigraphy of the Silurian turbidite sequence of North Greenland. Bull. Grønlands geol. Unders. 145, $121 \mathrm{pp}$.

Larsen, P.-H. \& Escher, J. 1985: The Silurian turbidite sequence of the Peary Land Group between Newman Bugt and Victoria Fjord, western North Greenland. Rapp. Grønlands geol. Unders. 126, 39-59.

Larsen, P.-H. \& Escher; J. in prep.: A sedimentological section through the Silurian turbidite sequence in northern Nyboe Land, North Greenland. Rapp. Gronlands geol. Unders.

Lowe, D. R. 1982: Sediment gravity flows. II. Depositional models with special reference to the deposits of high-density turbidity currents. J. Sed. Petr. 52, 279-297.

Middleton, G. V. 1967: Experiments on density and turbidity currents. III. Deposition of sediment. Can. J. Earth Sci. 4, 475-505.

Middleton, G. V. 1969: Turbidity currents and grain flows and other mass movements down slopes. In Stanley, D. J. (edit.) The new concepts of continental margin sedimentation. Am. Geol. Inst. Short Course Lecture Notes, pp. GM-A-1 to GM-B-14.

Middleton, G. V. 1970: Experimental studies related to prob- lems of flysch sedimentation. Geol. Ass. Can. Spec. Pap. 7, 253-272.

Middleton, G. V. \& Hampton, M. A. 1973: Sediment gravity flows: mechanics of flow and deposition. In Turbidites and deep-water sedimentation. Soc. Econ. Paleontologists Mineralogists, Pacific Section, Short Scourse Lecture Notes, 1-38.

Middleton, G. V. \& Hampton, M. A. 1976: Subaqueous sediment transport and deposition by sediment gravity flows. In Stanley, D. J. \& Swift, D. J. P. (edit.) Marine sediment transport and environmental management, 197-218. New York: Wiley.

Sanders, J. E. 1965: Primary sedimentary structures formed by turbidity current and related resedimentation mechanisms. Soc. Econ. Paleontologists Mineralogists Spec. Pub. 12, 192-219.

Skipper, K. \& Middleton, G. V. 1975: The sedimentary structures and depositional mechanics of certain Ordovician turbidites. Cloricorme Formation, Caspe Peninsula, Quebec. Can. J. Earth Sci. 12, 1934-1952.

Surlyk, F. \& Hurst, J. M. 1984: The evolution of the early Paleozoic deep-water basin of North Greenland. Geol. Soc. Am. Bull. 95, 131-154.

Walker, R. G. 1965: The origin and significance of the internal sedimentary structures of turbidites. Proc. Yorkshire Geol. Soc. 35, 1-32.

Wallis, G. B. 1969: One-dimensional two-phase flow. $408 \mathrm{pp}$. New York: McGraw-Hill.

Walton, E. K. 1967: The sequence of internal structures in turbidites, Scott. J. Geol. 3, 306-317. 